\title{
THE
}

\section{Terror by Telephone: Normative Anxieties around Obscene Calls in the 1960s}

Melissa Villa-Nicholas

University of Rhode Island, mvnicholas@uri.edu

Follow this and additional works at: https://digitalcommons.uri.edu/lsc_facpubs

The University of Rhode Island Faculty have made this article openly available.

Please let us know how Open Access to this research benefits you.

This is a pre-publication author manuscript of the final, published article.

Terms of Use

This article is made available under the terms and conditions applicable towards Open Access

Policy Articles, as set forth in our Terms of Use.

\section{Citation/Publisher Attribution}

Villa-Nicholas, M (May 2018). "Terror by Telephone: Normative Anxieties around Obscene Calls in the 1960s." First Monday. 23.5 Available at: http://dx.doi.org/10.5210/fm.v22i5.7010

This Article is brought to you for free and open access by the Graduate School of Library and Information Studies at DigitalCommons@URI. It has been accepted for inclusion in Graduate School of Library and Information Studies Faculty Publications by an authorized administrator of DigitalCommons@URI. For more information, please contact digitalcommons-group@uri.edu. 
"Terror by Telephone: Normative Anxieties around Obscene Calls in the 1960s"

Melissa Villa-Nicholas

Graduate School of Library and Information Studies

University of Rhode Island

melissavillanicholas@uri.edu 


\begin{abstract}
By 1967, telephone harassment complaints had hit an all-time high. The telephone companies, government officials, police, and media scrambled to make sense of and harness the surge in obscene calls. Such a phenomenon drew on the publics' fears of an unknown and anonymous 'pervert,' which now had access to their private sphere through the technology of telephone calls. Previous research has focused on obscenity laws and censorship with regards to cultural products, however neglects the gendered, sexual, and racialized implications of this historical window of obscene calls. The discourse around obscene calls during the 1960s demonstrates that the telephone shifted from a technology of progress to a technology of 'terror' that delivered the social anxieties around race, gender, and sexuality into the domestic sphere.
\end{abstract}

\title{
Introduction
}

In 1964, the Bell Telephone system received the highest number of obscene phone calls on record. By 1965, the calls in New York City alone increased by 30\% (Weinstock, 1966). Journalists, government representatives, and the Bell Company were stunned with the obscene phone call spectacle. Authorities met the phenomenon with a flurry of solutions, ultimately creating an Annoyance Call Bureau, shifting the technology of the telephone to develop more methods of tracing phone calls, amending the Communications Act of 1934, and making the obscene phone call a Federal offense. This short-lived phenomenon dwindled by the early 1970s after local and federal investigations, Bell advertisements, congressional hearings, and psychiatric analysis.

The telephone, a technology persistently equated by telephone companies with the narrative of 'progress' (Green, 2011) that represented possibilities of innovation in the U.S., 
had become a harbinger of the shifting norms around race, gender, and sexuality in the 1960s. Telephone historian John Brooks attempted to summarize this larger conversation that surfaced in the story of obscene phone calls:

The 'disorganization of American society and the weakening of American social norms that took place in the years after the assassination of President Kennedy...the venom of the poisoned, the bad blood of society, was spread through the national blood vessels of the telephone network (Brooks, 1976, p. 286).

As a historian of the telephone and Bell System, Brooks saw the disarray of the 1960s as reaching all through telephone lines. But the discourse around obscene phone calls may be seen as the story of national fear as race, gender, and sexuality visibly shifted; a presence unseen but brought into the homes through the anonymity of the telephone.

The public discourse around obscene phone calls in particular expressed social anxieties of the 1960s over race, sexuality, gender, and nationalism to shift the telephone from a 'safe' technology to a technology that threatened white heteronormativity.

I have researched primary and secondary sources to better understand the underlying social anxieties of the phenomenon of telephone harassment in the 1960s: This article uses news articles around this topic written in the 1960s; advertisements in 1960s newspapers that address telephone harassment; congressional records around the 1960s congressional hearings on telephone harassment; articles from psychiatric scholarship on the topic; and secondary source scholarly articles as primary and secondary evidence to understand the social discourse around telephone harassment. By highlighting media, corporate, and government sources around telephone harassment and obscene phone calls, 
this essay documents the discursive social anxieties around technology, nationalism, and sexuality.

This scholarship is motivated by the need for a thorough investigation on the national focus on obscene phone calls, and written to contribute to larger movements on the historical and social constructions of technologies, to expound on how obscene calls and the telephone transmitted anxieties around normativity in the 1960s. I first look at the Bell System's use of race and gender in the threatened white female victim of obscene phone calls. Next, I examine the U.S. governments' emphasis of the fallen Vietnam soldier to recover white masculinity and bring together the nation. Finally, I investigate the discourse around sexuality and gender as discussed by journalists and psychologists around obscene calls in the 1960s.

. This article demonstrates how the obscene phone calls manifested social fears around the cultural changes in the United States during the 1960s, providing new insights into the history of the technology of the telephone through a focus on nationalism, race, gender, and sexuality only briefly explored by previous scholars.

\section{Literature Review}

Previous literature has looked at the ways in which race and gender have coconstructed the making of the telephone and the telephone companies, and infrequent investigation into the social circumstances surrounding telephone harassment has been written.

From the late $19^{\text {th }}$ century, the telephone was founded on systems of race and gender, implemented in the American Telephone and Telegraph (AT\&T), also known as the Bell Company. These systems of oppression were implemented through the development 
of telephone access and services to a narrow group of white businessmen, a discrimination against people of color as employees, a white female 'gendering' around the role of telephone operators that denied them equal employee rights to their male counterparts, and the resistance to the inclusion of women of color at Bell that led to workplace hostility.

Early on, the telephone served a small pool of people, namely white upper class businessmen who used the speed of information sharing through the telephone to their advantage (Green, 2001 and Brooks, 1976). But even after the telephone became popularized, gender and race were used to mediate the publics' relationship to the telephone. By 1965 the United States underwent considerable changes around race, gender, and sexuality. The changing social structures of the United States, in turn, impacted discourse and interpretation of obscene phone calls and the telephone. The telephone was previously discussed as a 'safe' technology of progress that relayed a nostalgic sense of community through the operator who once mediated social exchanges of gossip with callers, invoking a more 'local' entity (Green, 2001). But as the technology changed, telephone calls shifted from party lines to private lines during the 1960s. Throughout the 1960s, with the creation of the Equal Employment Opportunities Commission (EEOC) through the Civil Rights Act of 1965, Bell came under great scrutiny for their unfair hiring practices and general employment discrimination towards white women and women and men of color (Green, 2001). The nostalgic community and technological determinism around the narrative of 'progress' and the telephone imagined by dominant member of societies was now gone. The telephone became a technological site where discourse around shifting structures of race, gender, and sexuality played out. 
Although historians of the telephone discussed this wave of telephone harassment, few have delved into the socio-political implications surrounding the change in legislation and technology. Lana Rakow, in exploring how gender is executed through and with the telephone, notes that the telephone was used as an instrument of harassment towards women during the window while phone calls were anonymized. In her study on gender and the telephone, Rakow found that Midwestern white women viewed calls as potentially threatening because of their experience of harassing phone calls. Venus Green has done extensive research on race, gender, and telephone operators. Harassing telephone calls are not color blind, and Green notes that black women telephone operators heavily experienced harassment by both telephone subscribers on the line, their supervisors at the Bell System, and their white co-workers. Green nods to the era of obscene calls, pointing to the racist harassment outside of the publics' discussion around obscene calls, however her work does not delve deeply into the context surrounding this era (Green, 2001).

The Black Bell operators were regularly harassed by their co-workers, managers, and through obscene phone calls. These forms of telephone harassment were not included on the record of obscene phone calls in the 1960s, but documented through Green's work (Green, 2001), “Managers accused the operators of 'playing' with the elevators, stealing 'cheap' cafeteria utensils, and leaving hair that 'looks like steel wool' in the bathroom sinks'” (Green, 2001, p. 222-223). Black operators often bore the brunt of severe racial and sexual harassment, and commanded by management to only respond with politeness. According to Green's interviews, callers would severely abuse black operators, "For example, you know, people will call up and,... say 'You are all a bunch of niggers.' Or more obscene things...about wanting to go to bed with you or something like that," (Green, p. 
$224,2001)$. Another operator discussed further the publics' specific response to women with deep southern accents, "Men would come on and say obnoxious things...would call them a bitch'" (Green, 2001, p. 225) Gabrielle Gemma testified in front of the FCC in detail about these harassing calls, "' Operators were often forced to endure such epithets as 'you black bitch.'” (Green, 2001, p. 225). These testimonies, though recorded for the impending EEOC v. AT\&T case, were specifically used for the consent decree around affirmative action and excluded around public discussion of obscene phone calls.

Telephone historian John Brooks attributed obscene phone calls to two factors: technological and sociological (Brooks, 1976). Because of rapid changes in technology, phone calls were less reliant on the telephone operator, resulting in a changeover from party lines to private lines that ensured a caller's privacy (Brooks, 1976). Second, as this article expands on, Brooks believed these calls resulted from the upheaval of social norms in America (Brooks, 1976, p. 286).

The particular phenomenon of telephone harassment during the 1960s has yet to be explored in depth. When contextualized with the national conversation around 'obscene phone calls,' the shift in technology and the change in the Communications Act were based on fixed race, gender, and sexual norms; such circumstances were used to serve technological determinism and patriotism. The era of obscene phone calls demonstrates how the telephone moved from a technology of progress to a 'technology of terror' in public discourse, conjured as a threat to heteronormativity, whiteness, and gendered relations already in upheaval in the 1960s United States. This essay provides new insights into the historical moment of obscene phone calls, expanding previous research by looking at the race, gender, sexuality, and nationalist implications. 


\section{Background}

AT\&T began as Bell in the $19^{\text {th }}$ century, when Alexander Graham Bell obtained a patent for his 'talking machine' (Danielian, 1939, p. 7), leading to the formation of a group of investors called the Bell Patent Association, and the inception of the Bell System (Danielian, 1939). In the $19^{\text {th }}$ century, the first users of the telephone were upper class businessmen, however a turn toward availability to the public made the telephone a commercial product by the late $19^{\text {th }}$ century (Johns, 2010). The New York Telephone Company, which plays a part in this article, was founded in 1883 as a subsidiary company of the Bell Telephone System, serving Long Island, Staten Island, and parts of New Jersey (New York and New Jersey, 2004). In 1885, AT\&T was established in New York, merging the telegraph and telephone service under one network and one holding company (John, 2010). By the early $20^{\text {th }}$ century, the telephone had become popularized throughout the United States. By the early $20^{\text {th }}$ century, the telephone had become popularized throughout the United States (John, 2010, p. 270). ${ }^{1}$ Despite their attempts, Bell was not the only operating company offering services. Because the Bell patent monopolies expired in the late $19^{\text {th }}$ century, 'Independent' non-bell Companies built up their patent portfolios, operating 2.4 million telephones in 1902, compared to Bell’s 3.1 million (John, 2010, p. 273). While Bell offered a larger network and a larger variety of calling plans, the

\footnotetext{
${ }^{1}$ John asserts that the popularization of the telephone was due to the network expansion of the political economy. State and municipal governments were given authority to regulate the phone company (John, 2010, p. 270-271). Congress put the telephone and telegraphs under the jurisdiction of the Interstate Commerce Commission (ICC) in 1910. In 1913, Bell and the Justice Department agreed on three provisions in the Kingsbury Commitment: the divestiture between Bell and Western Union, a mandate that Bell could not purchase independent operating companies, and to give independent companies access to Bell's long-distance network (John, 2010, p. 360).
} 
independents offered lower rates for local services (John, 2010, p. 274). But by 1907 the independent companies began to collapse, unable to compete with their Bell rival (John, 2010, p. 306-307).

Due to the heavy investment into Bell Laboratories, the telephone technology was changing rapidly by the 1960s. In the 1940s and 50s, long distance telephone calls were greatly improved by AT\&Ts development of a microwave relay system between New York and Boston (A Brief History, Corp.ATT.com), greatly enhancing long distance networks throughout the 1950s. International communications developed in the 1960s with the launch of AT\&Ts first commercial satellite, Telestar I, into orbit (A Brief History, corp.att.com). During the 1950s, telephone operator switchboards were reduced drastically through Direct Distance Dialing (DDD), when operators no longer connected many calls because of the development of Traffic Service Position (TSP).

According to the United States Census Bureau, by 1960, 4 out of 5 households had a telephone available (U.S. Census Bureau, 2011), with 41,618,040 telephones available to American's, and $21.5 \%$ of households with no telephone available (U.S. Census Bureau, 2011). In contrast to 1950 , when just $62 \%$ of U.S. households had landline telephone services (The History of the Telephone, U.S. Census Bureau), access to the telephone was expanding by decade at a rapid rate. Consistent jumps in telephone service in households around the United States were seen from 1960, with $78 \%$ of households accessing telephone service, to 1965 , when $85 \%$ of households had telephone service ( $20^{\text {th }}$ Century Statistics, 1999, p 885).

By 1966, Bell Telephone received 375,000 complaints about obscene phone calls, with an increase of 30\% of phone calls in New York City alone between 1964 and 1965 
(Weinstock, 1966), and were consistently documenting the calls with a monthly report to the FCC. However, these complaints barely indicated the actual amount of harassing phone calls circulating, estimated by the Federal Communications Commission (FCC) at around 568,000 in 11 months in 1966 (Robertson, 1967). Individual states' legislation took on the obscene calls by introducing similar bills. By 1965, the Senate Commerce Committee's Subcommittee on Communications, chaired by Democratic Senator John Pastore of Rhode Island, introduced a bill making obscene phone calls a federal crime (Farrar, 1965). S.375 was passed by the Senate in April 1967. In 1968 the Subcommittee on Communications and Power heard testimonies from members of the House, the Chairman of the FCC, the Department of Defense, AT\&T, and the National Association of Regulatory Utility Commissioners, all requesting the adoption of the bills that were being adapted in individual states. By 1968 the House of Representatives' Committee on Interstate and Foreign Commerce was referred the bill S. 375 in order to amend the Communications Act of 1934 (Staggers, 1968). Obscene phone calls became a public discussing point because of the shift from party lines to private lines in the early 1960s. Previous and after the public awareness of obscene phone calls, black telephone operators experienced obscene phone calls through racial and sexual harassment, as telephone customers became increasingly aware of workplace integration at Bell (Green, 2001).

Each major outlet confronting the issue- the Bell System, the media, psychologists, and the U.S. government- approached obscene phone calls differently. To motivate a shift in telephone technology that would help trace the caller's number, the Bell System took a gendered tactic, relying on their already built in system of white femininity framed the development of the telephone in the U.S. to act as a motivator for stopping obscene calls. 
Obscene calls, as represented by Bell Telephone, were positioned as a threat to fragile white femininity. Black women telephone operators, often harassed by customers through phone lines, were virtually ignored as one of these victims.

Whereas congress and media focused on families of Vietnam veterans as victims of obscene calls to change the law, the Bell System focused on gender and whiteness. The use of white femininity was not new to the Bell System that deeply embedded with race, gender, and class norms into the role of the telephone operator. White women operators were hired specifically for their middle class status and gendered social skills, directed to placate businessmen customers in the late $20^{\text {th }}$ century (Green, 2001, p. 3). Until the mid$21^{\text {st }}$ century, white women continued as operators to the general public, benefitting from the prestige of their segregated work place, viewed as more elite than factory workers and lower class labor (Norwood, 1990). Whiteness and gender, as manufactured by Bell management, perpetuated femininity as a social skill and class symbol in place of higher wages and quality of life benefits (Green, 2001). Race and gender employment segregations at Bell began to shift during the 1940s, due to the post-World War II employment sector, when companies such as Bell were ordered to hire more African-American employees under the Fair Employment Practices Committee (FEPC) (Green, 2001). As the workplace was racially integrated, the image of the 'white lady' telephone operator declined because Bell restructured the workforce to diminish the 'elite' operator status (Green, 2001, p. 196). As a result, telephone subscribers and white telephone operators regularly harassed newly hired Black operators (Green, 2001). For the telephone operator, the decline of the 'white lady' image and integration of black women were used as a method of control in the workplace, manipulating white workers through threatening their jobs by hiring racial 
minorities (Green, 2001, p. 226). Bell management also decreased the privileges previously afforded to white operators, such as free coffee, tea, and comfortable lunchrooms (Green, 2001, p. 220). Telephone workers of color lacked union representation, as union officials saw themselves only acting on behalf of white workers' interests, viewing new minority hiring as a threat to white union members' jobs (Green, 2001, p. 228). The white female victim of obscene phone calls, then, came natural to Bell's own historical precedent of organizing race and gender accordingly.

White employees in large private companies such as Bell resisted workplace integration through the 1960s. Meanwhile, uprisings and civil rights movements drew negative attention to the Bell system. Reports of discrimination and low numbers of recruitment and retention of people of color and white women placed Bell in the spotlight of workplace integration (Brooks, 1976, p. 288). The role of the telephone operator, based on a white, middle-class female to 'soothe' customers experiencing equipment malfunctions was built around an idealized service specialist. Though paid lower wages and working in grueling labor conditions, the telephone operator could differentiate herself from immigrant and lower class laborers in factories (Green, 2001). When black women were integrated into the workplace during the 1950s and 1960s, the middle class privileged image of the telephone operator was intentionally removed by Bell, and the new African American operators were harassed regularly. Black operators were expected to be polite despite racial and sexual harassment from the subscribers, and customers especially abused women with southern accents (Brooks, 1976).

Despite extensive hearings in Congress, news coverage, and changes to state and federal laws, at no point was the racist and sexual harassment of black telephone operators 
discussed in these public forums. The harassment of black operators, in the office and on the telephone line, never surfaced as a part of the larger narrative of obscene calls. Instead, white femininity was visualized as Bell's top concern.

Operators and subscribers were being harassed during this time period. Black operators were harassed racially and sexually; there was little media coverage around black telephone operator harassment ${ }^{2}$, AT\&T did not shape their own policy and advertisements around black operator telephone operator harassment, and the congressional investigations into obscene phone calls did not take these forms of harassment into account. Subscribers harassment was discussed on a national level and explore by all three of these outlets: AT\&T, the U.S. Congress, and the media.

Historians of the telephone have traditionally looked at the political economy, labor, gender, and race surrounding the formations of obscene phone calls. This research includes a consideration of sexuality and nationalism. I conclude that the telephone is a technology that 'moves' in the public eye according to social fears manifesting in the U.S. during the time period of obscene calls, the mid and late 1960s.

\section{Discourse Around the Telephone Harassment Victims}

Despite workplace integration, the case of obscene telephone calls was presented as visually segregated, wherein white females were conjured by Bell as the only victims, and testimonies from black women were entirely excluded. Obscene phone calls were a new singularity in the United States, due to the shift in telephone technology from party lines to private lines in the early 1960s (Brooks, 1976). At the time, telephone companies, law

\footnotetext{
${ }^{2}$ Investigating in depth the spectrum of racialized harassment that black telephone operators is beyond the scope of this article, and is explored fully by Venus Green's work Race on the Line.
} 
officials, and the victims of these calls could not trace the caller, leaving those on the receiving end limited in their response to anonymous calls.

The Bell System acted quickly, creating an Annoyance Call Bureau to handle the calls, and began to develop technologies that could trace the calls and reveal the caller (Pastore, 2967). Bell also regularly ran advertisements on 'What you can do about obscene harassing or threatening calls.' As such, Bell advertisements became the conduit of imagined victims and callers, visually revealing the threatened white woman by an anonymous, but all too real, voice on the line.

As a part of the Bell campaign against obscene phone calls, advertisements were frequently run in mainstream newspapers and women's magazines from 1966 to 1969 . The advertisements, sponsored by the regional Bell provider, generally kept to the same text and illustrated message. In various news outlets across the country, the advertisement showed a delicate white manicured hand reaching for a telephone, detached from the rest of her body. The advertisements first advised the victim of an obscene call to not respond, hang up, and to call the Bell System if the calls continued (Farrar, 1965). The advertisements name women as the most frequent victims of obscene calls. According to a 1966 advertisement in the Los Angeles Times:

Women are the most frequent targets of obscene and harassing phone calls- a source of serious concern to us. If you're a woman, this ad is especially for you...First of all, remember that the troubled individuals who make obscene calls are just looking for an audience- usually a female one (Pacific Telephone, 1969, p. B5). From Pacific Telephone on the west coast to Illinois Bell Telephone in the Midwest, to New York Telephone on the east coast, each Bell subsidiary advertisement on obscene calls 
included a picture of a delicate white hand, manicured nails, some with fashionable bangles, reaching for the dial phone in their home (Illinois Bell, 1966, p. 87).

The advertisements ran, albeit less frequently, through 1974, when a Ladies' Home Journal issue had a special focus for New York area women, "Anonymous and obscene phone calls plague women in every city, and particularly in New York. All too often, the victims unwittingly attract the menace themselves" (New York Times, 1974). The language of the advertisements engages the same gendered 'comfort' and 'soothing' originally used to train operators in the late $19^{\text {th }}$ and early $20^{\text {th }}$ century, "If the calls continue, don't hesitate to phone your Illinois Bell Service Representative. She can call in people we have specially trained to help investigate, identify, and work with police in the apprehension of these callers" (Chicago Tribune, 1966).

The calls towards women often began with a male caller who initiated conversation with a female, only to bait them into obscene language. These calls were discussed as obscene in a sexual nature, "A current trap for the unwary is the telephone survey. It's used by both burglars and perverts in the District. The perverts use the survey to entice the housewife into carrying on an innocent conversation before the caller moves into obscenity" (USA Congressional Record, 1966, p. 1186). Another victim felt threatened based on her status living alone,

"In recent weeks a woman who lives alone in a midtown apartment has received several phone calls late at night from a man who made led suggestions...Realizing he knows who she is and where she lives, she is terrified and doesn't know what to do." (Weinstock, 1966) 
While vulnerable femininity framed the obscene calls crisis for AT\&T, Bell turned back to masculinity to 'fix' the problem via innovation and technological surveillance.

The crisis of obscene calls motivated Bell to spend millions of dollars on technology that could trace calls back to the caller. At the beginning of the obscene call trend in 1966, phone companies such as the New York Telephone Company established an Annoyance Call Bureau would have the phone subscriber record their unwanted calls over seven days. After the week of screening, the bureau would screen all incoming calls, which would eventually lead to obtaining the caller's number (Pastore, 1966, p. 4). Bell Labs focused on developing faster techniques to finding the obscene caller with enhanced technology. The Sun reporter Thomas J. Fleming verbalized the masculinity associated with technological progress in tracing obscene calls, even going so far as to position engineers as 'hunters,' "The telephone men have worked out a highly efficient routine to supplement mechanical hunting equipment" (Fleming, 1966). Joel Dinerstein notes that masculinity makes up a part of the techno-cultural matrix of the West, invoking independence, innovation, and modernity through technology (Dinerstein, 2006, p.571). Bell hoped that shifting the conversation toward masculinity and innovation could amend the image of the telephone, now challenged through obscene calls.

Bell detailed three different systems of surveillance during the hearings on harassing phone calls, clarifying that the technology was not a wire-tapping device. Mr. Hubert Kertz of AT\&T testified on behalf of the Bell System for the Senate. Kertz detailed three new techniques invented to trace calls. The first was a 'Tone Set', described as: A box equipped with an on-and-off switch and connected by a wire to the annoyed customer's telephone. When a crank call is received, the customer flips the switch 
which places a 20,000-cycle tone on the circuit and also activates an alarm in the central office, alerting a switchman on duty to start tracing the call. This tone cannot be heard by either party to the telephone call (Pastore, 1966, p. 5).

The second tracing technology was named a 'Pen Register.' The Pen Register attached to the line of a prime suspect of obscene calls. When activated, the pen recorded the dialing pulses, resulting in the number and time of the call (Pastore, 1966). Finally, the third device, called the 'Tap Circuit' acted as a computer operated from a central office. The device recorded the calling number, called number, date, and time on a punch card (Pastore, 1966). Under the new Bell surveillance technology, 358 callers were convicted in 1965, 788 callers in 1966, and 1,105 were convicted in 1967 (Pastore, 1966, p. 3). The new monitoring technologies were lauded for their assistance in catching the perpetrator, thus rescuing the threatened white female victim.

The strategy by Bell in confronting the influx in obscene phone calls harnessed white femininity as the most vulnerable victim, motivating customers to respond to obscene phone calls and shifting technology. Gendered attributes already ascribed to operators were used to convey a sense of safety back on the line. Black telephone operators, regularly harassed on and off the lines according to their race and gender, were virtually ignored in the public discourse around obscene calls. Although white women were displayed by Bell as visual victims of obscene calls, government officials attempting to change legislation on the federal level drew on the image of the families of the fallen Vietnam soldier.

For its time, the case of obscene phone calls stands out from the surrounding public discussions around obscenity. Debates around obscenity were heavily confronted in 
mainstream media and in the courts, however more frequently through literature and culture. The translation of Henry Miller's erotic novel Tropic of Cancer was confiscated from readers by police and prosecuted for obscenity charges, and William S. Burroughs' Naked Lunch also went to trial for obscenity (De Grazia, 1993). Comedian Lenny Bruce was also on trial for his 'obscene' language use in public (De Grazia, 1993). Pornography, obscene language, and homosexuality were all on trial for censorship in the mid 1960s, but the telephone was not identified as one of the monumental cases that shifted the legality of 'obscenity' in the U.S.

The telephone acted as a medium for obscenity to move into the domestic sphere. The obscene phone call went to trial through the Senate Commerce Committee's Subcommittee on Communications. Whereas Bell approached the national crisis of obscene calls through white femininity and technological resources, government officials focused on the attack on masculinity through the fallen Vietnam soldier, justifying the amendment of the Communications Act of 1934 to make obscene calls a national crime.

\section{Vulnerable Masculinity, Nationalism, and the Communications Act}

Previous to the Senate Committee hearings on obscene phone calls, individual states had taken measures against the wave of obscene phone calls, creating statutes that would allow the caller, if apprehended, to be charged funds and jail time (Pastore, 1966, p. 3). By 1965, the Senate Commerce Committee's Subcommittee on Communications, chaired by Democratic Senator John Pastore of Rhode Island, introduced a bill making obscene phone calls a federal crime (Farrar, 1965). Although women were generally acknowledged as the most commonly targeted for telephone harassment, the Senate Hearings and media focused on families of fallen Vietnam War soldiers who received malicious calls. The turn in 
focus on soldiers' families would serve to bring the nation back together around the absent white male body, rather than of women, who received the bulk of the obscene calls.

The historical context of masculinity in the Vietnam War is extremely relevant here. The Vietnam War was as a gendered war, wherein masculinity and male soldiers were visually represented, and women were removed from representation (Sturken, 1997). The Vietnam War has been depicted as a time when American masculinity was in crisis (Sturken, 1997, p. 70). Male Vietnam veterans were now able to take on the role of the 'victim' by American society and government, gaining sympathy as an 'oppressed' subject (Jeffords, 1989). Communications scholar Marita Sturkin argues that the Vietnam War was defined by the crisis in masculine identity in the United States, while simultaneously prompting national sympathy, not because of soldiers' experience in Vietnam, but their treatment after the war (Jeffords, 1989, p. 70). The focus on Vietnam soldiers and their families as victims of obscene calls, then, presumes to evoke the fragmented masculinity of fallen soldiers as a symbol of sympathy and a rallying point for further support of the ongoing war. Susan Jeffords, in her analysis of Vietnam War literature and film, argues, "Gender is the primary narrative of Vietnam War representation, remasculinity its primary aim" (Sturkin, 1997, p. 112). But the case of obscene calls narrative moved beyond U.S. popular culture and throughout the national conversation around information technologies.

Hearings on obscene calls led by Senator Pastore focused on families of Vietnam War veterans from early on, to motivate national action traditionally approached on the state level. Some surmised that the focus on family's of veterans and subsequent action was a political statement, one that rallied the nation back around a singular issue and 
condemned 'indecency' and 'obscenity' often associated with the gender and sexual statements arising in the U.S. public's consciousness,

These themes of censorship and defining obscenity, indecency, and profanity have recurred over the sixty years since the passage of the Act. In the sixties and seventies political tensions associated with the Vietnam War and changing social mores gave rise to questions about obscenity and indecency across phone lines and radio lines (Paglin, et al., 1999, p. 125).

In congressional proceedings during January 1966, Senator Pastore labeled obscene calls to widows and parents of servicemen as the "most cruel and vicious of all involved calls," (Pastore, 1966, p. 1186) and named the fallen soldier as a "Vietnam victim" (Pastore, 1966, p. 1186) rather than a victim of U.S. military action. Thus, the hearings focused primarily on these families, avoiding calls based on sexual and racial harassment (Kramarae, 1988, p. 194). The 'Vietnam victim,' politicians found, was a launching point to rally citizens back around nationalism and away from mainstream issues of race, gender, and sexuality often intertwined with 'indecency' and 'obscenity' in the national dialogue.

Families of fallen soldiers or Vietnam veterans were often told that their family member or loved one had been injured or was taunted over the already deceased. The caller would give false reports of death or injury, "or even, hard to believe, are gloatingly reminded of the death of a son or husband in the service" (Pastore, Senate, Report No. 1334, 1966 p. 2).

Although some families of soldiers killed in the Vietnam War were harassed, surveys and statistics resist the narrative that these were the primary focus of callers. General William W. Berg, Deputy Assistant Secretary of Defense for Military Personnel Policy, 
conducted a 'spot check' of military bases and found that most of the crank calls were unrelated to fallen soldiers of the Vietnam War (Pastore, 1967, p. 5). Of the 500 harassing calls made to 9 military bases, 87 of those calls were related to the Vietnam War (Pastore, 1967, p. 4). By 1967, the number dropped considerably, down to 50 family members related to military operations oversees, out of the 641,821 complaints on record that year (The Baltimore Sun, 1967).

One of the main targets of Senator Pastore and the Subcommittee of Communications was to amend the Communications Act, created by the Federal Communications Commission (FCC) in 1934. The Communications Act of 1934 had been challenged around obscenity and indecency a number of times since its establishment, often based on the struggle to keep the government from censuring radio waves (Paglin et al., 1999). According to Senator Pastore, not enough states had prohibited the use of obscene language over the telephone, advocating for a federal approach (USA Congressional Record, 1966). This amendment specified what constituted obscenity through the telephone:

...Whoever by means of telephone communication in interstate or foreign commerce- (1) makes any comment, request, suggestion, or proposal which is obscene, lewd, lascivious, filthy or indecent; or (ii) anonymously makes a call or calls in a manner reasonably to be expected to annoy, abuse, torment, threaten, harass, or embarrass one or more persons; or (iii) makes repeated calls with intent to annoy, abuse, torment, threaten, harass, or embarrass one or more persons; or (iv) knowingly permits any telephone under his control to be used for any purpose prohibited by this section- shall be fined not more than $\$ 1,000$ or imprisoned not 
more than one year, or both. Each such telephone call or use shall constitute a separate offense (USA Congressional Record, 1966).

Although Bell first resisted support of federal law, hoping to deal with obscene calls internally, they too endorsed the legislation, trusting that it would deter potential offenders through fees and imprisonment (Pastore, 1967). Bell hoped that such a change in the Communications Act would assist in regulation over 'Wide Area Telephone Service' (WATS), dealing with interstate calls and long distance service. In spite of support from the Senate and Bell System, The Justice Department opposed the bill, arguing that enforcement of obscene calls should be "kept in the hands of the state" (The Washington Post, 1966). Ultimately, the change in the Communications Act became Public Law 90-299 by adding Section 223, making obscene, abusive, or harassing telephone calls across State boundaries a federal offense punishable by a fine of $\$ 500$ or imprisonment for up to 6 months (Paglin et al., 1999, p. 126). But the 'problem' of interstate calls was also exaggerated, only numbering 500 of the 500,000+ obscene calls in 1966 (House of Representatives Report No. 1109, 1968).

While white women were placed as 'visual' victims in the public imaginary through Bell's ad space on obscene calls, motivating changes in surveillance technologies, the fallen U.S. soldier from the Vietnam War was used as a rallying cry by government officials and mainstream newspapers to bring the nation back together. The absent white male body in the fallen soldier and the present, fragile white feminine hands reaching for the telephone are conjured in response to those 'social crisis' of the 1960s that, as many worried, tore the nation apart. These victims of obscene calls, then, were prey to the fissures in race, gender, and sexuality that lurked 'out there,' and could now come into their homes through the 
anonymity of the telephone. Who were those heavy-breathers that intruded the home on the phone lines? For journalists and the public, a sexual 'pervert' sought to threaten the private sphere. But according to police reports and psychologists, in reality the caller was much more likely closer to the victim.

\section{The Caller: Perverts, Monsters, and Terrorists}

As obscene calls increased and senate hearings gained traction, journalists, government officials, and psychologists grasped at explaining who the callers were and why they made obscene calls. The callers were generally named 'perverts,' reported to suffer sexual and domestic crisis. In most reports, the perpetrators were men, often known to the recipient of the call. The telephone, the obscene callers medium, also became a threatening presence.

These callers were named 'telephone terrorists,' out to bring horror through the telephone. According to Thomas J. Fleming of The Sun, "All of these people discovered to their horror that the telephone, that miracle of modern convenience, the prototype of the $20^{\text {th }}$ century's technological revolution, can become an instrument of terror, a weapon" (1966). Fleming's observation encircles the nation's larger preoccupation with the sexual and gender revolutions of the 1960s. A previously assumed safe tool, such as the telephone, was now the harbinger of all things eroding in society. Indeed, Mrs. Patricia Glow, a spokesperson for a group of Long Beach housewives, lamented, "Alexander Graham Bell's miracle has become a monster" (Los Angeles Times, 1966). Mr. Staggers from the Committee on Interstate and Foreign Commerce noted,

"Since its invention, the telephone has been the source of many and great benefits to the American people. But recently its use has been perverted by some to make it an 
instrument for inflicting incalculable fear, abuse, annoyance, hardship, disgust, and grief on innocent victims, who, in many instances, are young women and children" (House of Representatives, Report No. 1109, 1968, p. 2).

Who was the man behind the receiver? The obscene phone caller, named a national 'pervert,' and the telephone named as 'monster,' had shifted the technological determinism of the telephone that marked it as 'good' in efficiency, progress, capitalism, and safety, into a tool of terror. The anonymous caller was assumed to be a man whose sexuality had been so perverted by modern society that he had no other outlet but the telephone.

The public's diagnosis around obscene callers circulated through the media beyond the coded language of 'perverts' and 'monsters' (USA Congressional Record, 1966, p.1186). Contextualized with the medical standards of the time and growing fears of the public discourse around sexuality, the obscene caller manifested as a threat heteronormativity. Fleming reported in 1966 around various callers. Fleming clearly identified that callers were already known to the victim, such as acquaintances, family, and friends, "Disappointed suitors, business, enemies, relatives or neighbors harboring secret grudges seem particular prone to use the telephone" (Fleming, 1966) But Fleming identified the caller's motives as 'complex,' "Some psychiatrists have speculated that he is a latent homosexual who basically hates women and derives special pleasure from the fear and outrage he arouses" (Fleming, 1966). In describing obscene callers, public discourse alluded to the social anxieties around homosexuality. Fleming's profile of a fictional 'homosexual man' who hated women was unfounded (Fleming, 1966). However callers did manifest around anxieties and expectations of heteronormativity, and the resentment towards women's changing gender role also served to motivate obscene calls. 
During this time researchers found that threatened sexuality often influenced the caller. Conversely from the allusions in the press and government hearings, the psychoanalytic reports on obscene calls did not point to 'homosexuality' as the cause for calls. In his own case studies, Nadler found that the callers, all white and male, were motivated by "the exhibitionist's morbid fear of his own inadequacy; and to gain, through the responses of others, whether that response be positive or negative, a transient sense of power and importance" (Nadler, 1968, p. 522). The caller used the telephone as a medium to be anonymous and 'take back' his sense of lost heterosexual power. In Nadler's study, the caller identified women as a particular target because they felt threatened by them, naming women as "two-faced but powerful. Telephoning expressed some rage. It attempted to neutralize the destructive power of women" (Nadler, 1968, p. 523) Obscene callers, according to these psychological studies, generally fit a profile of heterosexual males threatened with shifting gender roles among women and the challenges to the heteronormative lifestyle in the 1960s.

The perpetrators of obscene calls were not limited to heterosexual-identified strangers. Often the obscene caller, like other crimes, was more than likely known to the victim. In one instance, a man had twenty of his friends call to harass his wife at work (USA Congressional Record, 1966, p. 1186), which Fleming related to a "family's domestic crisis" (1966) In some instances the callers were girls and women, often identified as married wives bored at home because their husbands "worked nights" (Fleming, 1966). Additionally, a young babysitter was caught in New Jersey who made hundreds of calls in three years, and two girls in New Jersey, ages 11 and 14, made more than 75 calls to a local tavern (Fleming, 1966). Although apprehended as obscene callers, girls and women 
obscene callers were not studied at this time for psychoanalytic evaluation. Another common caller reported were recorded messages from a right-wing political group in Sarasota Florida who specifically targeted the National Council of Churches, Parent Teacher Association, and politicians for being 'soft on communism.' (Farrar, 1965)

As the above has illustrated, the obscene phone caller was feared to be a 'pervert' who turned the telephone into a 'monster' and technology of 'terror.' Such anxieties around threatened gender, sexuality, and nationalism manifested themselves in the imagined anonymous caller, who could now enter the domestic sphere, once a safe space of the nuclear family. But in reality, the victim of obscene calls often knew the caller; obscene callers were frequently husbands, housewives, young girls, and political groups. The telephone became a technology that manifested the normative fears and threats to nationality, race, sexuality, and gender that were destabilizing in the 1960s.

\section{Conclusion}

By the 1970s, harassing phone calls declined significantly, leading to less public discussion around the subject and a large decline in Bell advertisements (Pacific Telephone, 1969). The Baltimore Sun reported that families of Veterans experienced considerably less harassing calls by as early as 1967 (The Baltimore Sun, 1967), although Bell Telephone recorded 640,000 complaints in 1968 (Paglin et al., 1999). Telephone harassment did not end, but the public discourse around the phenomenon, its victims, and the harassers, did fade. The national media, advertisements by the telephone company, and congressional hearings receded by the end of the $60 \mathrm{~s}$. The terror of the telephone that surfaced so suddenly in the mid-1960s ebbed by the early 1970s. However black operators continued to be harassed throughout the 1970s, according to their testimony during the Equal 
Employment Opportunity Commission's discrimination case against AT\&T in 1972 (Brooks, 1976).

As I have sought to illustrate here, in the short span of a few years, the telephone, in the public eye, shifted from an American technology of progress, to a harbinger of threat to race, gender and heteronormativity, and shifted back again to a safe technology, via innovation, amending the Communications Act of 1934, and implementing a national criminalization of obscene calls. The distinct approaches between the Bell System, the newspapers, government officials, and psychologists suggests that different systems of authority approached obscene calls according to the larger system of social anxieties circulating at the time. The Bell System used a gendered whiteness approach familiar to their foundations of telephone service. Government officials and the media conjured the image of the fallen Vietnam soldier in conveying the attack on masculinity with obscene calls, attempting to reunite the nation over the absented white male. Finally, journalists and psychologists described the telephone and obscene calls through rhetoric that invoked an attack on heteronormativity.

Established as a technology of progress in the U.S., the telephone quickly became a tool that threatened social norms and could be delivered into the domestic, private sphere of usually safe and normative homes. The dissonance with the telephone suggests that technology acts as a site of dominant public anxieties around race, gender, nationalism, and sexuality. While the telephone was described as 'monster' and 'terror,' upheaving technological determinism ingrained in the telephone's narrative, it was made 'safe' again through technological innovation, surveillance, and government legislation through federal criminalization. While the shift in technology of the telephone was blamed for delivering 
obscene calls into the home during the 1960s, the improvement of the same technology through further surveilling devices was also lauded as 'fixing' the problem. A 1969 Los Angeles Sentinel advertisement for Pacific Telephone lauded the company's rapid decrease of obscene calls, "With the aid of modern electronic detection devices, many of these callers have been identified. And through law enforcement agencies many cases have resulted in arrests and convictions. We want to do all we can to protect your privacy" (Pacific Telephone, 1969). Technological 'progress' coupled with state punishment enforcement were credited for correcting the social chaos of the 1960s telephone lines.

Overall, this essay illustrates that obscene phone calls in the 1960s provided a platform for expressing anxiety around the race, gender, sexual, and national changes in society. Furthermore, the telephone itself was a no longer a 'safe' technology, but now had the potential to deliver outsider threats to normativity into the domestic sphere. The Bell System, the U.S. government, and psychologists all worked to fix obscene phone calls, moving the telephone back into a 'safe' technology once again. As a whole, this article seeks to demonstrate that by tracking race, gender, sexual, and national contexts of the history of the telephone can we gain a full appreciation of the how discourse and changes around technology is motivated by social norms.

\section{About the author}

Melissa Villa-Nicholas is an Assistant Professor of the Graduate School of Library and Information Studies at the University of Rhode Island. Her work looks at the intersections of race, gender, and sexuality around the constructions and interactions of information technologies. Melissavillanicholas@uri.edu 


\section{References}

Brooks, J. (1976). Telephone: the first hundred years. New York: Harper \& Row.

Dinerstein, J. (2006). Technology and its discontents: On the verge of the posthuman. American Quarterly. 58:3. 571.

De Grazia, E. (1993). Girls Lean Back Everywhere. New York: Random House.

Farrar, F. (November 19, 1965). Bell asks chance to deal with phone hate messages. Chicago Tribute.

Fleming, T.J. (1966, August 28). Terror by telephone. The Sun.

Green, V. (2001). Race on the line : gender, labor, and technology in the Bell System,18801980. Durham, N.C. : Duke University Press.

Harassment of Viet GI Kin Called Less. (1967, February 17). The Baltimore Sun.

House of Representatives. (1968, February 27). “Obscene, Abusive, and Harassing Telephone Calls." Report No. 1109, submitted by Mr. Staggers from the Committee on Interstate and Foreign Commerce.

Illinois Bell. (1966, March 23). Chicago Tribune. A10.

Illinois Bell. (1966, April 28). Newsday, 87.

Jeffords, S. (1989). The temasculinization of America: Gender and the vietnam war. Bloomington: Indiana University Press.

John, R. (2010). Network nation: Inventing American telecommunications. Cambridge, MA: Belknap Press of Harvard University Press.

Kramarae, C. (ed.) (1988). Technology and women's voices. London: Routledge.

(Former) New York and New Jersey telephone and telegraph company. (2004, June 29). Landmarks Preservation Commission. 
Nadler, R. (1968, February 15). Approach to psychodynamics of obscene telephone calls." New York State Journal of Medicine.

Never underestimate the power of a woman. (1974, September 29). New York Times.

Norwood, S. (1990). Labor's flaming youth: telephone operators and worker Militancy, 1878-1923. Urbana : University of Illinois Press.

Pacific Telephone Advertisement. (1969, April 24). Los Angeles Sentinel.

Paglin, M.D., Hobson, J.R., and Rosenbloom, J. (Eds.) (1999). Golden jubilee commission on telecommunications. Silver Spring : Pike \& Fischer.

Pastore, J. (1966, June 27). Abusive and harassing telephone calls." Senate Report No. 1334, 4.

Pastore, J. (1967, April 19). Abusive and harassing telephone calls. Senate Report No. 189 from the Committee on Commerce.

Pacific telephone advertisement. (1969, March 18). Los Angeles Times. B5.

Phone sale pitches hit as danger to elderly. (1966, October 5). Los Angeles Times.

Rakow, L. (1992). Gender on the line: Women, the telephone, and community life. Urbana: University of Illinois Press.

Robertson, N. (1967, February 17). Phone call abuse shows sharp rise. New York Times.

Senate Passes Obscene Calls Bill. (1966, June 30). The Washington Post.

Staggers, H. (February 27, 1968). Obscene, Abusive, and Harassing Telephone Calls. House of Representatives. Report No. 1109. 20th Congress 2d session.

Sturken, M. (1997). Tangled memories: The Vietnam war, the AIDS epidemic, and the politics of remembering. Berkeley: University of California Press. 
USA Congressional Record. (1966, January 10- January 27, 1966). Proceedings and Debates of the $89^{\text {th }}$ Congress Second Session. Volume 112- Part 1.

U.S. Census Bureau, Housing and Household Economic Statistics Division. Last Revised October 31, 2011. Accessed at https://www.census.gov/hhes/www/housing/census/historic/phone.html .

U.S. Census Bureau. (1999). Statistical Abstract of the United States. Accessed https://www2.census.gov/programs-surveys/sis/activities/history/eh3_teacher.pdf

U.S. Census Bureau. (1999). "20 th Century Statistics." Statistical Abstract of the United States.

Weinstock, M. (1966, August 9). Would you believe 376,000 anonymous obscene calls? Los Angeles Times. 